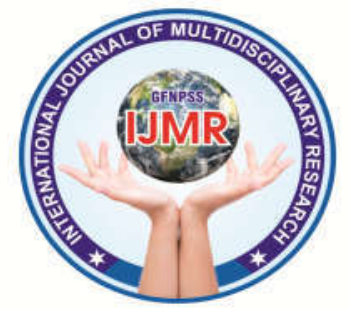

ISSN (0): 2582-693X

Original Article

\title{
SEX DETERMINATION BY MANDIBULAR CANINE INDEX IN KOTA POPULATION-A COMPARATIVE STUDY
}

\author{
DR. RAVIKUMAR S. KULKARNI, ${ }^{1}$ DR. AMIT NANDWANA, ${ }^{2}$ DR. SHOHA H. \\ PATEL ${ }^{3}$ \\ ${ }^{1}$ Professor and Head, ${ }^{2}$ Senior Lecturer, ${ }^{3}$ Post graduate student, Department of Oral \\ Pathology and Microbiology, Daswani Dental College and Research Centre, Kota, Rajasthan, \\ India.

\section{Corresponding Email:ravioralpathology@gmail.com}

\begin{abstract}
Background: the four main attributes of biological identity that most forensic osteologists hope to determine are the sex, age, stature, and ethnic background of the individual. The estimation of sex is more reliable if the complete skeleton is available but in forensic cases human skeletal remains are often incomplete or damaged. In such cases teeth are good material in living and non-living population for anthropological, genetic, odontologic, and forensic investigations.
\end{abstract}

Methods: the study population constituted of 200 subjects inclusive 100 males and 100 females with age range of 18-25. Measurements made in $\mathrm{mm}$ at the contact point were mesiodistal width of right and left canine, intercanine distance both intraorally and on casts and mandibular canine index were calculated. The obtained data was subjected to $t$ test $/ \mathrm{mann}$ whitney test and discriminant function analysis.

Results: All parameters of mandibular canines namely inter canine distance, canine width and canine index were greater in males compared to females suggesting significant sexual dimorphism of mandibular canines. Left canine width was greater compared to right canine width in both males and females. Right canine index casts were strongly significant among all the parameters. On subjecting the data to discriminant function analysis it classified sex correctly in $73 \%$ of samples.

Conclusion: Results of the study establishes existence of significant sexual dimorphism in mandibular canines. We can therefore recommend the use of mandibular canine dimensions as an applicable method for gender determination in human identification.

Keywords: Forensic anthrology, gender determination, mandibular canine. 


\section{INTRODUCTION}

Human beings have come a long way from the early caveman age to the present day. His intelligence has also led to a surge in crime rate, terrorism, wars, mass disasters, road traffic accidents and dreadful diseases. In all such incidents the identity of the deceased, assailant or the cause of death becomes important, as the core of various investigations are based on these processes. ${ }^{1}$

The four main features of biological identity are sex, age, stature, and ethnic background. ${ }^{2}$ Sex assessment of skeletal remains is an important step in building the biological profile of unidentified skeletons recovered in forensic contexts. It enables a more focused search of missing person files, with the potential of recovering antemortem records for comparison and establishing identity. ${ }^{3}$

It is widely agreed that the skull and pelvis are the most useful skeletal regions for sex determination. Krogman and Iscan ranked skeletal regions in order of their accuracy for determining sex: the pelvis $95 \%$, the skull $92 \%$, the mandible 90\% and long bones (humerus and femur) $80 \%{ }^{4}$
Sexual dimorphism represents a group of morphologic characteristics that differentiate a male from a female. Among these dimorphic traits, tooth size has been evaluated in various populations for its applicability in anthropologic and forensic investigations. The morphological differences of the teeth between males and females have been reported and can be applied to identify the gender from dental remains. ${ }^{5}$

Although the morphology of the tooth structure is similar in males and females, the size of tooth does not necessarily remain the same, as the tooth size is determined by cultural, environmental, racial and genetic factors. ${ }^{6}$ Earlier studies showed that sexual dimorphism have been observed in permanent maxillary anterior teeth, ${ }^{7}$ maxillary molars, ${ }^{8}$ mandibular canines and mandibular molars. ${ }^{9}$ The least dimorphic teeth were the lower lateral incisor and the lower central incisor. ${ }^{10}$ But canines have consistently shown the greatest sexual dimorphism; moreover, they are robust in terms of resistance to disease and trauma and more likely to remain intact in postmortem scenarios. ${ }^{11}$ The mandibular canines are not only exposed to less plaque, calculus, abrasion from brushing, 


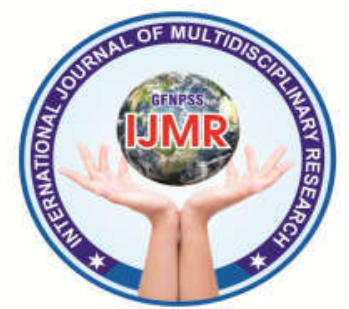

or heavy occlusal loading than other teeth, they are also less severely affected by periodontal disease and so, usually are the last teeth to be extracted with respect to age. $^{12}$

\section{MATERIALS AND METHOD}

200 subjects (100 males and 100 females) between the age group of 18-25 years were selected from patients reporting to the O.P.D in Daswani dental college and research center, Kota, Rajasthan after taking written consent from the patient. The study was approved by the ethical review board of the college.

The subjects with the following criteria were included in the study: healthy gingiva and periodontal status, mandibular canines free from dental caries, normal overjet and overbite of teeth (2-3 $\mathrm{mm})$, absence of spacing in the anterior teeth and Angle's Class 1 molar and canine relationship. Subjects with partially erupted or ectopically erupted teeth, missing teeth, occlusal abnormalities, teeth showing physiologic or pathologic wear and tear and with history of trauma and orthodontic treatment were excluded from the study.

Measurements were made intraorally and later on the casts obtained from the same subjects using digital Vernier caliper
(Mitutoyo, Japan; Resolution-0.01mm; Accuracy- $\quad+/-\quad 0.02 \mathrm{~mm}$ ). Alginate impression of mandibular arch was made using perforated metallic impression tray and the cast was poured using type III dental stone.

Greatest mesiodistal dimension was considered as the tooth width. Right and left mandibular canine width was measured intraorally and on the casts. Intercanine width was measured from the cusp tip of right mandibular canine to the cusp tip of left mandibular canine. Mandibular canine index (MCI) was calculated using the following formula Mandibular canine index=Mesio-distal width of mandibular canine

Intercanine distance

Sexual dimorphism in right and left mandibular canines was calculated using formula given by Garn \& Lewis (1967) as follows:

Sexual dimorphism $=\frac{\mathrm{Xm}_{-}-1 \times 100}{\mathrm{Xf}}$

Where $\mathrm{Xm}=$ Mean canine width of males

$\mathrm{Xf}=$ Mean canine width of females

The measurements obtained were subjected to $t$ test/ mann whitney test and discriminant functional analysis 


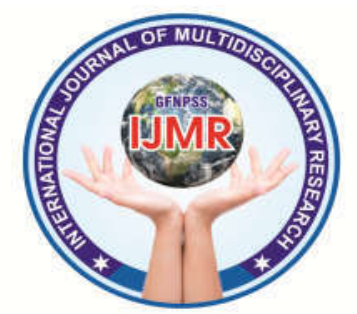

Photograph - Mesiodistal width of

mandibular canine.

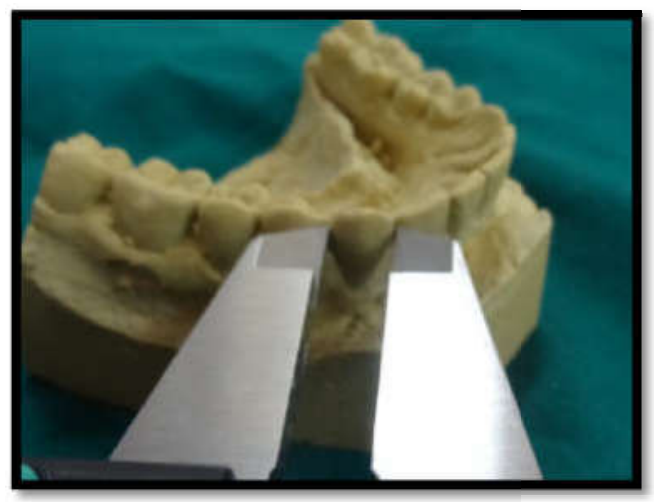

Photograph - Mandibular Intercanine

distance.

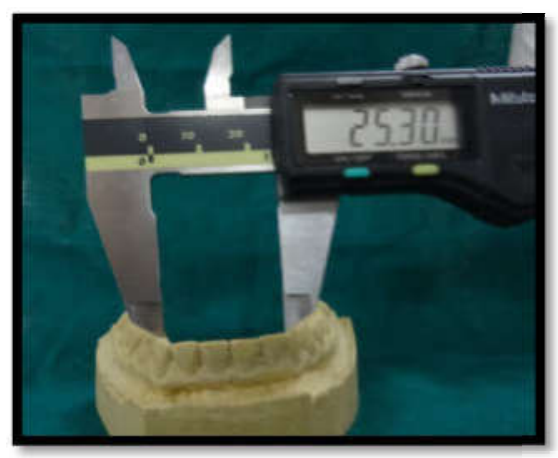

\section{RESULTS}

The data was collected, tabulated and subjected to statistical analysis. The results are as follows:

Table 1:Comparison of different parameters between males \& females:

\begin{tabular}{|c|c|c|c|c|c|c|c|c|}
\hline Parameter & Group & Gender & Mean & $\begin{array}{l}\text { Std } \\
\text { Dev }\end{array}$ & $\begin{array}{l}\text { SE of } \\
\text { Mean }\end{array}$ & $\begin{array}{l}\text { Mean } \\
\text { Difference }\end{array}$ & $t / z$ & P-Value \\
\hline \multirow{4}{*}{$\begin{array}{l}\text { Intercanine } \\
\text { Distance }\end{array}$} & \multirow[b]{2}{*}{ Intraoral } & Male & 26.36 & 1.56 & 0.16 & \multirow{2}{*}{0.894} & \multirow{2}{*}{-3.929} & \multirow{2}{*}{$<0.001^{*}$} \\
\hline & & Female & 25.46 & 1.69 & 0.17 & & & \\
\hline & \multirow{2}{*}{ Casts } & Male & 26.18 & 2.52 & 0.25 & \multirow{2}{*}{0.711} & \multirow{2}{*}{-3.823} & \multirow{2}{*}{$<0.001^{*}$} \\
\hline & & Female & 25.47 & 1.69 & 0.17 & & & \\
\hline \multirow{4}{*}{$\begin{array}{l}\text { Right } \\
\text { Canine } \\
\text { Width }\end{array}$} & \multirow[b]{2}{*}{ Intraoral } & Male & 6.81 & 0.41 & 0.04 & \multirow{2}{*}{0.435} & \multirow{2}{*}{7.456} & \multirow{2}{*}{$=0.001^{*}$} \\
\hline & & Female & 6.37 & 0.41 & 0.04 & & & \\
\hline & \multirow{2}{*}{ Casts } & Male & 6.81 & 0.41 & 0.04 & \multirow{2}{*}{0.433} & \multirow{2}{*}{7.427} & \multirow{2}{*}{$<0.001^{*}$} \\
\hline & & Female & 6.37 & 0.41 & 0.04 & & & \\
\hline \multirow{4}{*}{$\begin{array}{l}\text { Left } \\
\text { Camine } \\
\text { Width }\end{array}$} & \multirow[b]{2}{*}{ Intraoral } & Male & 6.91 & 0.40 & 0.04 & \multirow{2}{*}{0.447} & \multirow{2}{*}{7.940} & \multirow{2}{*}{$<0.001^{*}$} \\
\hline & & Female & 6.46 & 0.39 & 0.04 & & & \\
\hline & \multirow{2}{*}{ Casts } & Male & 6.91 & 0.40 & 0.04 & \multirow{2}{*}{0.517} & \multirow{2}{*}{6.201} & \multirow{2}{*}{$<0.001^{*}$} \\
\hline & & Female & 6.39 & 0.73 & 0.07 & & & \\
\hline \multirow{4}{*}{$\begin{array}{l}\text { Right } \\
\text { Camine } \\
\text { Index }\end{array}$} & \multirow[b]{2}{*}{ Intraoral } & Male & 0.26 & 0.01 & 0,00 & \multirow{2}{*}{0.007} & \multirow{2}{*}{-3.618} & \multirow{2}{*}{$<0.001^{*}$} \\
\hline & & Female & 0.25 & 0.02 & 0.00 & & & \\
\hline & \multirow{2}{*}{ Casts } & Male & 0.26 & 0.01 & 0.00 & \multirow{2}{*}{0.008} & 3665 & $=0001 \%$ \\
\hline & & Female & 0.25 & 0.01 & 0.00 & & -3.005 & $<0.001^{\circ}$ \\
\hline & & Male & 0.26 & 0.02 & 0.00 & 0008 & 3661 & \\
\hline 60 & Intraoral & Female & 0.25 & 0.01 & 0.00 & 0.006 & -9.001 & \\
\hline & Casts & Male & 0.26 & 0.02 & 0.00 & & & \\
\hline & Casts & Female & 0.25 & 0.01 & 0.00 & 0.00 & -5.015 & \\
\hline
\end{tabular}

I Mamn-Whitney test

* denotes significant difference

t-test/ Mann- Whitney test was applied to compare different parameters between males and females.

\section{Intercanine distance}

\begin{tabular}{|c|c|c|c|c|c|c|c|c|}
\hline Parametele & Group & Gender & Jean & $\begin{array}{l}\text { Sidd } \\
\text { Dert }\end{array}$ & $\begin{array}{l}\text { SE of } \\
\text { Weatl }\end{array}$ & $\begin{array}{c}\text { Mean } \\
\text { Difference }\end{array}$ & th & $\begin{array}{c}\text { P. } \\
\text { Vilue }\end{array}$ \\
\hline \multirow{4}{*}{$\begin{array}{l}\text { Iintercanine } \\
\text { Distance" }\end{array}$} & & Male & 26.36 & 1.56 & 0.16 & \multirow{2}{*}{0.894} & \multirow{2}{*}{.3992} & \multirow{2}{*}{$0.001^{8}$} \\
\hline & Intraoral & Female & 25.46 & 1.69 & 0.17 & & & \\
\hline & & Nale & 26.18 & 252 & 0.25 & \multirow{2}{*}{0711} & \multirow{2}{*}{.38223} & \multirow{2}{*}{$0.001^{8}$} \\
\hline & Cas & Female & 25.47 & 1.60 & 0.17 & & & \\
\hline
\end{tabular}

of 200 subjects (100\%), 100 males ( 50\%) had mean intercanine distance of 26.36: SD of 1.56 intraorally; mean value of 26.18: SD 2.52 in casts. 100 females $(50 \%)$ had mean 


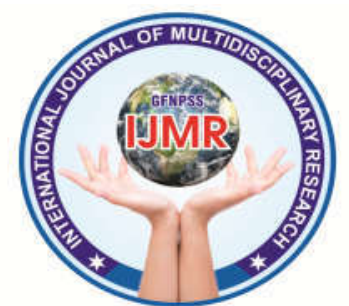

intercanine distance of 25.46: SD of 1.69 intraorally; mean value of 25.47: SD of 1.69 in

casts. The values were significantly higher in males compared to females with $p$ value $<0.001$.

\section{Right canine width}

\begin{tabular}{|c|c|c|c|c|c|c|c|c|}
\hline Parameter' & Group & Gender & Mean & $\begin{array}{l}\text { Std } \\
\text { Der }\end{array}$ & $\begin{array}{l}\text { SE of } \\
\text { Ment }\end{array}$ & $\begin{array}{c}\text { Meall } \\
\text { Difference }\end{array}$ & th & \begin{tabular}{|c|} 
P. \\
Value \\
\end{tabular} \\
\hline \multirow{4}{*}{$\begin{array}{l}\text { Right } \\
\text { canine } \\
\text { width }\end{array}$} & \multirow[b]{2}{*}{ Intraoral } & Male & 6.81 & 0.41 & 0.04 & \multirow{2}{*}{0.435} & \multirow{2}{*}{7.456} & \multirow{2}{*}{$<0.001^{*}$} \\
\hline & & Female & 6.37 & 0.41 & 0.04 & & & \\
\hline & \multirow{2}{*}{ Casts } & Male & 6.81 & 0.41 & 0.04 & \multirow{2}{*}{0.433} & \multirow{2}{*}{7.427} & \multirow{2}{*}{$0.001^{*}$} \\
\hline & & Female & 6.37 & 0.41 & 0.04 & & & \\
\hline
\end{tabular}

Of 200 subjects (100\%), 100 males $(50 \%)$ had mean right canine width of 6.81: SD 0.41 intra orally; mean value of $6.81: \mathrm{SD}$ 0.41 in casts. 100 females $(50 \%)$ had mean right canine width of 6.37: SD 0.41 intraorally; mean value of 6.37: SD 0.41 in casts. The values were significantly higher in males compared to females with $p$ value $<0.001$.

\section{Left canine width}

\begin{tabular}{|c|c|c|c|c|c|c|c|}
\hline Panmetel & Gloup & Getide' & Ueall & Stid & $\begin{array}{l}\text { SE of } \\
\text { IETI }\end{array}$ & $\begin{array}{c}\text { Ueall } \\
\text { Jefference }\end{array}$ & th \\
\hline \multirow{4}{*}{$\begin{array}{l}\text { Let coine } \\
\text { wilh }\end{array}$} & \multirow[b]{2}{*}{ Introtal } & Male & 601 & 0.4 & ONA & \multirow{2}{*}{0.47} & \multirow{2}{*}{7.94} \\
\hline & & Femile & 646 & 039 & 0.14 & & \\
\hline & \multirow{2}{*}{ Cas: } & Male & 691 & 0.1 .1 & 0.04 & \multirow{2}{*}{0.17} & \multirow{2}{*}{6.01} \\
\hline & & Femile & 630 & 077 & 0.07 & & \\
\hline
\end{tabular}

Of 200 subjects $(100 \%), 100$ males $(50 \%)$ had mean left canine width of 6.91: SD 0.40

intraorally; mean value of 6.91: SD 0.40 in casts. 100 females $(50 \%)$ had mean left canine width of 6.46: SD 0.39 intraorally; mean value of 6.39: SD 0.73 in casts. The values were significantly higher in males compared to females with $\mathrm{p}$ value $<0.001$.

Right canine index

\begin{tabular}{|c|c|c|c|c|c|c|c|c|}
\hline Parametel' & Group & Gender & Men & $\begin{array}{l}\text { Std } \\
\text { Der }\end{array}$ & $\begin{array}{l}\text { SE of } \\
\text { Mena }\end{array}$ & $\begin{array}{c}\text { Meall } \\
\text { Difference }\end{array}$ & t/ & $\begin{array}{c}\text { P- } \\
\text { Value }\end{array}$ \\
\hline \multirow{4}{*}{$\begin{array}{l}\text { Right } \\
\text { canine } \\
\text { index' }\end{array}$} & \multirow[b]{2}{*}{ Intraoral } & Male & 0.26 & 0.01 & 0.00 & \multirow{2}{*}{0.007} & \multirow{2}{*}{-3.618} & \multirow{2}{*}{$0.001^{8}$} \\
\hline & & Female & 0.25 & 0.02 & 0.00 & & & \\
\hline & \multirow{2}{*}{ Casts } & Male & 0.26 & 0.01 & 0.00 & \multirow{2}{*}{0.008} & \multirow{2}{*}{-3.665} & \multirow{2}{*}{$0.001^{*}$} \\
\hline & & Female & 0.25 & 0.01 & 0.00 & & & \\
\hline
\end{tabular}

Of 200 subjects (100\%), 100 males $(50 \%)$ had mean right canine index of 0.26: SD 0.01

intraorally; mean value of 0.26 : SD 0.01 in casts. 100 females $(50 \%)$ had mean right canine index 0.25: SD 0.02 intraorally; mean value of 0.25 : SD 0.01 in casts. The values

were significantly higher in males compared to females with $\mathrm{p}$ value $<0.001$.

\section{Left canine index}




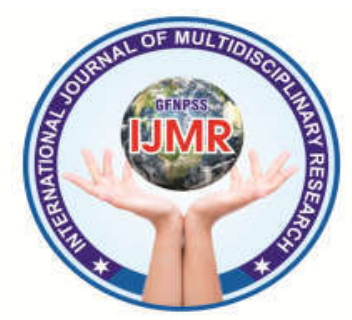

\begin{tabular}{|c|c|c|c|c|c|c|}
\hline ?armetel' Group & Getidel & Jena & $\begin{array}{ll}\text { Stil } & \text { SE of } \\
\text { Der } & \text { Nean }\end{array}$ & $\begin{array}{l}\text { Meall } \\
\text { Difference }\end{array}$ & th & $\begin{array}{c}\text { P. } \\
\text { lalutu: }\end{array}$ \\
\hline \multirow{4}{*}{$\begin{array}{l}\text { Leftcuns? } \\
\text { modex }\end{array}$} & Male & 0.26 & $\left(\begin{array}{ll}1.02 & 0.00\end{array}\right.$ & \multirow{2}{*}{0.003} & \multirow{2}{*}{$\therefore 606$} & \multirow{2}{*}{$(0.00]^{4}$} \\
\hline & Fendace & 025 & $\begin{array}{ll}0.01 & 0.00 \\
\end{array}$ & & & \\
\hline & Male & 0.26 & $0.02 \quad 0.00$ & \multirow{2}{*}{0.003} & \multirow{2}{*}{.6773} & \multirow{2}{*}{0.001} \\
\hline & Fendere & 0.25 & $\begin{array}{ll}0.01 & 0.00\end{array}$ & & & \\
\hline
\end{tabular}

Of 200 subjects (100\%), 100 males (50\%) had mean left canine index of 0.26: SD 0.02

intraorally; mean value of 0.26 : SD 0.02 in casts. 100 females $(50 \%)$ had mean left canine index of 0.25 : SD 0.01; mean value of 0.25 : SD 0.01 in casts. The values were significantly higher in males compared to females with $\mathrm{p}$ value $<0.001$.

Table 2:Comparison of different parameters within males between intraoral and casts:

\begin{tabular}{|c|c|c|c|c|c|c|c|}
\hline Parameter & Group & Mean & Std Dev & $\begin{array}{l}\text { SE of } \\
\text { Mean }\end{array}$ & \begin{tabular}{|l|} 
Mean \\
Difference \\
\end{tabular} & $\mathrm{t} / \mathrm{z}$ & P-Value \\
\hline \multirow{2}{*}{$\begin{array}{l}\text { Intercanine } \\
\text { Distance }^{\mathrm{f}}\end{array}$} & $\begin{array}{l}\text { Intra } \\
\text { Oral }\end{array}$ & 26.36 & 156 & 0.16 & \multirow{2}{*}{0.182} & \multirow[t]{2}{*}{-0.038} & \multirow{2}{*}{0.970} \\
\hline & Casts & 26.18 & 2.52 & 0.25 & & & \\
\hline \multirow{2}{*}{$\begin{array}{l}\text { Right } \\
\text { Canine } \\
\text { Width }\end{array}$} & Intra & 6.81 & 0.41 & 0.04 & \multirow{2}{*}{0.001} & \multirow{2}{*}{0.021} & \multirow{2}{*}{0.984} \\
\hline & Casts & 6.81 & 0.41 & 0.04 & & & \\
\hline \multirow{2}{*}{$\begin{array}{l}\text { Left } \\
\text { Canine } \\
\text { Width }\end{array}$} & $\begin{array}{l}\text { Intra } \\
\text { Oral }\end{array}$ & 6.91 & 0.40 & 0.04 & \multirow{2}{*}{-0.006} & \multirow{2}{*}{-0.109} & \multirow{2}{*}{0.904} \\
\hline & Casts & 6.91 & 0.40 & 0.04 & & & \\
\hline \multirow{2}{*}{$\begin{array}{l}\text { Right } \\
\text { Canine } \\
\text { Indes" }\end{array}$} & Intra & 0.26 & 0.01 & 0.00 & \multirow{2}{*}{0.000} & \multirow{2}{*}{-0.028} & \multirow{2}{*}{0.978} \\
\hline & $\begin{array}{l}\text { Untal } \\
\text { Casts }\end{array}$ & 0.26 & 0.01 & 0.00 & & & \\
\hline \multirow{2}{*}{$\begin{array}{l}\text { Left } \\
\text { Canine } \\
\text { Index }\end{array}$} & Intra & 0.26 & 0.02 & 0.00 & \multirow{2}{*}{0.000} & \multirow{2}{*}{-0.004} & \multirow{2}{*}{0.997} \\
\hline & $\begin{array}{l}\text { Oral } \\
\text { Casts }\end{array}$ & 0.26 & 0.02 & 0.00 & & & \\
\hline
\end{tabular}

1. In male sample size of $100(50 \%)$, the mean intercanine distance was 26.36 intraorally and 26.18 in the casts. No significant difference was observed between intraoral and casts with $\mathrm{p}$ value $>0.05$.
2. In male sample size of $100(50 \%)$, the mean right canine width was 6.81 intraorally

and 6.81 in the casts. The mean left canine width was 6.91 intraorally and 6.91 in the casts. No significant difference was observed between intraoral and casts with $\mathrm{p}$ value

$>0.05$.

3. In male sample size of $100(50 \%)$, the mean right canine index was 0.26 intraorally

and 0.26 in the casts. The mean left canine index was 0.26 intraorally and 0.26 in the casts. No significant difference was observed between intraoral and casts with $\mathrm{p}$ value

$>0.05$.

Table :Comparison of different parameters within females between intraoral and casts:

\begin{tabular}{|c|c|c|c|c|c|c|c|}
\hline Parameter & Group & Mean & Std Dev & \begin{tabular}{|l|l|} 
SE of \\
Mcan
\end{tabular} & \begin{tabular}{|l|} 
Mean \\
Difference
\end{tabular} & $t z$ & P-Value \\
\hline \multirow{2}{*}{$\begin{array}{l}\text { Intercaume } \\
\text { Distance }\end{array}$} & \begin{tabular}{|l|} 
Intra \\
Oral
\end{tabular} & 25.46 & 1.69 & 0.17 & \multirow{2}{*}{0.002} & \multirow{2}{*}{0.016} & \multirow{2}{*}{0.987} \\
\hline & \begin{tabular}{|l|} 
Casts \\
\end{tabular} & 25.47 & 1.69 & 0.17 & & & \\
\hline \multirow{2}{*}{$\begin{array}{l}\text { Right } \\
\text { Canine } \\
\text { Width }\end{array}$} & $\begin{array}{l}\text { Intra } \\
O_{1 y a l}\end{array}$ & 6.37 & 0.41 & 0.04 & \multirow{2}{*}{-0.001} & \multirow{2}{*}{-0.021} & \multirow{2}{*}{0.984} \\
\hline & \begin{tabular}{|l} 
Uall \\
Casts \\
\end{tabular} & 6.37 & 0.41 & 0.04 & & & \\
\hline \multirow{2}{*}{$\begin{array}{l}\text { Left } \\
\text { Canine } \\
\text { Width }\end{array}$} & \begin{tabular}{|l|} 
Intra \\
Oral
\end{tabular} & 6.46 & 0.32 & 0.04 & \multirow{2}{*}{0.064} & \multirow{2}{*}{0.776} & \multirow{2}{*}{0.439} \\
\hline & Cusits & 6.39 & 0.73 & 0.07 & & & \\
\hline \multirow{2}{*}{$\begin{array}{l}\text { Right } \\
\text { Camiue } \\
\text { Index }^{1}\end{array}$} & Intra & 0.25 & 0.02 & 0.00 & \multirow{2}{*}{0.001} & \multirow{2}{*}{-0.038} & \multirow{2}{*}{0.970} \\
\hline & \begin{tabular}{|l} 
Casts \\
\end{tabular} & 0.25 & 0.01 & 0.00 & & & \\
\hline \multirow{2}{*}{$\begin{array}{l}\text { Lef } \\
\text { Canine } \\
\text { Indes }\end{array}$} & $\begin{array}{l}\text { Intra } \\
\text { Ural }\end{array}$ & 0.25 & 0.01 & 0.00 & \multirow{2}{*}{0.000} & \multirow{2}{*}{-0.029} & \multirow{2}{*}{0.977} \\
\hline & \begin{tabular}{|l} 
Casts \\
\end{tabular} & 0.25 & 0.01 & 0.00 & & & \\
\hline
\end{tabular}

1. In female sample size of $100(50 \%)$, the mean intercanine distance was 25.46 intraorally and 25.47 in the casts. No 


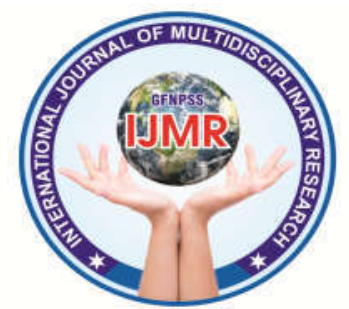

significant difference was observed and females failed the tolerance test due to between intraoral and casts with $p$ value high fluctuancy. So they are not included $>0.05$. in

2. In female sample size of $100(50 \%)$, the the final discriminant model.

mean right canine width was 6.37 Using Fisher's linear discriminant intraorally

and 6.37 in the casts. The mean left canine width was 6.46 intraorally and 6.39 in the casts. No significant difference was observed between intraoral and casts with $\mathrm{p}$ value function, co-efficient of each parameter was determined. In males (50\%) intercanine distance-intraoral (X1) is 1876.94, intercanine distance-casts (X2) is 6.08 , right canine width-intraoral (X3) is -4585.10 , left canine width-intraoral (X4) $>0.05$.

3. In female sample size of 100 (50\%), the mean right canine index was 0.25 intraorally and 0.25 in the casts. The mean left canine index was 0.25 intraorally and 0.25 in the casts. No significant difference was observed between intraoral and casts with $p$ value $>0.05$.

The data acquired from sample size of 200 (100\%) including males $100(50 \%)$ and females $100(50 \%)$ was subjected to discriminant function analysis. All the parameters

was found to be statistically significant in determining the gender.

Two parameters namely, right canine width and left canine index in casts of both males is -2843.31 , left canine width-casts (X5) is 40.23 , right canine index-intraoral (X6) is -385.38 , right canine index-casts (X7) is 120666.72, left canine index-intraoral (X8) is 71058.19 .

In females (50\%) intercanine distanceintraoral (X1) is 1877.68, intercanine distancecasts (X2) is 6.23, right canine width-intraoral (X3) is -4588.68 , left canine widthintraoral (X4) is -2845.50 , left canine width-casts (X5) is 39.77 , right canine indexintraoral (X6) is -372.97 , right canine index-casts $(\mathrm{X} 7)$ is 120743.66, left canine indexintraoral (X8) is 71047.75

The equations thus formed are:

$$
\begin{aligned}
& \mathrm{M}=\mathrm{C}+(1876.94) * \mathrm{X} 1+(6.08) * \mathrm{X} 2- \\
& (4585.10) * \mathrm{X} 3-(2843.31) * \mathrm{X} 4+ \\
& (40.23) * \mathrm{X} 5-(385.38) * \mathrm{X} 6+ \\
& (120666.72) * X 7+(71058.19) * X 8
\end{aligned}
$$




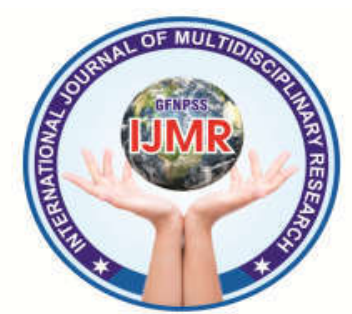

$\mathrm{F}=\mathrm{C}+(1877.68) * \mathrm{X} 1+(6.23) * \mathrm{X} 2-$ teeth. $^{16}$ The present study aimed to $(4588.68) * \mathrm{X} 3-(2845.50) * \mathrm{X} 4+$ delineate sexual dimorphism existing in $(39.77) * X 5-$

$(372.97) * \mathrm{X} 6+(120743.66) * \mathrm{X} 7+$ $(71047.75) * X 8$

\section{DISCUSSION}

The determination of sex is an important concern of the osteologist and the forensic anthropologist as it is critical for individual identification. ${ }^{14}$ Teeth exhibit the least turnover of natural structure and are readily accessible for examination. Being the hardest and chemically the most stable tissues in the body they are selectively preserved and fossilized, thereby providing by far the best record for evolutionary change. ${ }^{15}$

Sexual dimorphism represents a group of morphologic characteristics that differentiate male from a female. Sexual dimorphism in tooth size has been explored over the past half-century, with odontologists and anthropologists. ${ }^{13}$

Among the teeth, canines have consistently shown the greatest sexual dimorphism; moreover, canines are robust in terms of resistance to disease and trauma and more likely to remain intact in postmortem scenarios. ${ }^{11}$ Most studies have found mandibular canines to exhibit the greatest sexual dimorphism among all 


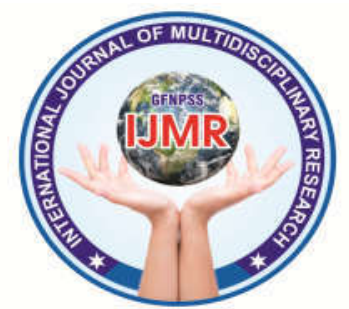

with females and was statistically significant. But reverse dimorphism was observed in study conducted by Karen Boaz et $\mathrm{al}^{17}$ in south Indian population who considered mesiodistal and buccolingual dimensions.

In our study measurements of left mandibular canine width was higher, compared to right mandibular canine width in both males and females. This difference was in agreement with studies conducted by Karen Boaz et al, ${ }^{17}$ Garn et al, ${ }^{19}$ Krishnamurthy Anuthama et $\mathrm{al}^{20}$ in permanent mandibular canines.

In the present study the left mandibular canine showed a greater sexual dimorphism (6.96\%) when compared to the right mandibular canine $(6.90 \%)$. This finding was consistent with studies conducted by Rishab Kapila et $\mathrm{al}^{70}$ and Kaushal et $\mathrm{al}^{15}$.

In our study the values of canine index were greater in males compared with females and

statistically significant. We found the mandibular canine index relevant in determining

sexual dimorphism of mandibular canines. This finding was consistent with studies conducted by Kaushal et al, ${ }^{15}$ Vandana M Reddy et al, ${ }^{12}$ Irfan Ahmed Mughal et al. ${ }^{23}$
M.Muller et $\mathrm{al}^{24}$ conducted a study and concluded that when mandibular anterior teeth alignment is not correct, gender determination is not possible using mandibular canine index. Contrasting results were got by Ashith B. Acharya et al, ${ }^{25}$ who conducted a study in Nepalese population to validate mandibular canine index as a sex predictor. Their results suggest that mandibular canine index has little reliability in sex assessment and its application should be restricted.

In the present study intraoral and cast measurements of mandibular canines were exact and equally good. So either of the two can be used for calculations. All parameters of mandibular canines namely inter canine distance, canine width and canine index were greater in males compared to females suggesting significant sexual dimorphism of mandibular canines. The left mandibular canine width was greater compared with right mandibular canine width in both males and females suggesting left mandibular canine to be more sexually dimorphic. This method is relatively simple, time saving and economical. Mandibular canine dimensions can be useful to corroborate gender of human remains with a high degree of certainty 


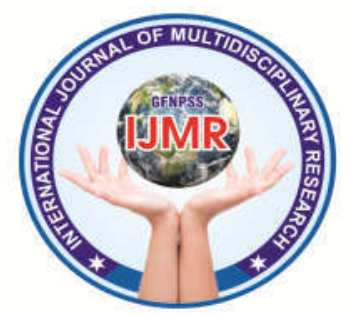

especially in cases of major catastrophes when bodies are often damaged beyond recognition.

\section{BIBLOGRAPHY}

1. Pandey A, Singh I, Pandey S, Vidya M. Role and responsibility of dentist as forensic odontologist. JKPractioner 2012 Jan-Sep;17(1-3):8082.

2. Schuer L. Application of Osteology to Forensic Medicine. Clinical Anatomy 2002;15:297-312.

3. Ruengdit S, Riengrojpitak S, Tiensuwan M, Santiwong P. Sex Determination from Teeth Size in Thais. The 6th CIFS Academic Day 2011;1-12.

4. Ozer I, Katayama K, Sagir M, Gule E. Sex Determination Using the Scapula in Medieval Skeletons from East Anatolia. Coll. Antropol. 2006;30(2):415-419.

5. Omar A, Azab S. Applicability of Determination of Gender from Odontometric Measurements of Canine Teeth in a Sample of Adult Egyptian Population. Cairo Dental Journal 2009;25(2):167-180.

6. Narang SR, Mandhanda AS, Arora PC, Kaur G. Sexual dimorphism in permanent 1st molar: A forensic tool.
Indian Journal of Comprehensive Dental Care 2012;2(2)224-227.

7. Pereira C, Bernardo M, Pestana D, Santos JC, Mendonca MC. Contribution of teeth in human forensic identification Discriminant function sexing odontometrical techniques in Portuguese population. Jounal of Forensic and Legal Medicine 2010;17:105-110.

8. Rai B, Jain RK, Duhan J, dutta S, Dhattarwal SK. Importance of maxillary first molar for sex determination. The Internet Journal of Dental Science. 2007;4(2).

9. Prabhu S, Acharya AB. Odontometric sex assessment in Indians. Forensic Science International 2009;192:129e1$129 \mathrm{e} 5$.

10. Soubayroux IP, Signoli M, Dutour O. Sexual dimorphism in teeth: discriminatory effectiveness of permanent lower canine size observed in a XVIIIth century osteological series. Forensic Science International 2002;126:227-232. 


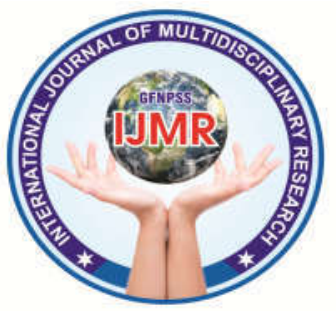

11. Acharya AB, Angadi PV, Prabhu S, Nagnur S. Validity of the mandibular canine index (MCI) in sex prediction: Reassessment in an Indian sample. Forensic Science International 2011;204:207e1-207e4.

12. Reddy VM, Saxena S, Bansal P. Mandibular canine index as a sex determinant: A study on the population of western Uttar Pradesh. J Oral Maxillofac Pathol 2008;12:5659.

13. Acharya AB, Mainali S. Are dental indexes useful in sex assessment? J Forensic Odontostomatol 2008;27(2):53-59.

14. Phoophalee P, Prasitwattanaseree S, Riengrojpitak S, Mahakkanukrauh P. Seax determination by patella measurements in Thais. 1st ASEAN Plus three graduate research congress 2012.

15. Kaushal S, Patnaik VVG, Agnihotri G. Mandibular Canines In Sex Determination. J Anat. Soc. India 2003;52(2)119-124.

16. Parekh D, Zalawadia A, Ruparelia S, Patel S, Rathod SP, Patel SV. Study Of Mandibular Canine Teeth Dimorphism In Establishing Sex
Identity In Gujarat Region. NJIRM 2011;2(2):6-9.

17. Boaz B, Gupta C. dimorphism in human maxillary and mandibular canines in establishment of gender. J Forensic Dent Sci 2009;1(4)4244.

18. Morgan J. Metric sexual dimorphism in permanent canines. Bull Int Assoc Paleodont. 2011;5(1)4-12.

19. Garn SN, Swidler DR, Kerewsky RS. Genetic control of sexual dimorphism in tooth size. J Dent Res 1967;46:963.

20. Anuthama K, Shankar S, Ilayaraja V, Kumar GS, Rajmohan M, Vignesh et al Determining dental sex dimorphism in South Indians using discriminant function analysis. Forensic Science International 2011;212:86-89.

21. Murshid Z, Hashim HA. Mesiodistal tooth width in a Saudi population:A preliminary report. The Saudi Dental Journal 1993;5(2)68-72. 